\title{
フッ化アンモニウム水溶液による水晶の水熱育成
}

\author{
橋本 慎 - 矢崎英毅 $\cdot$ 小平紘平 $*$
}

福島東洋通信機(株)，960-06 福島県伊達郡保原町字東野崎 60

*北海道大学工学部, 060 札幌市北区北13条西 8 丁目

\section{Hydrothermal Growth of Quartz from Ammonium Fluoride Solution}

\author{
Shin HASHIMOTO, Eiki YAZAKI and Kohei KODAIRA*
}

\author{
Fukushima Toyo Communication Equipment Co., Ltd., 60, Higashinozaki, Hobara-machi, Date-gun, Fukushima \\ *Faculty of Engineering, Hokkaido University, Nishi 8, Kita 13, Kita-ku, Sapporo-shi 060
}

960-06

[Received March 24, 1993; Accepted July 13, 1993]

The solubility of quartz from ammonium fluoride solution was measured using a small autoclave. Based on the solubility data, a single crystal of quartz was grown from ammonium fluoride solutions at $230-280^{\circ} \mathrm{C}$ and 4-101 MPa. The growth rate depended on the growth temperature, temperature gradient and concentration of the ammonium fluoride solution. The maximum growth rate of the $Z$ face attained was $0.88 \mathrm{~mm} /$ day which was comparable to that in alkaline solutions. However, the growth rate of the $X$ face was very low, the growth rate of $-X$ face was less than one fifth of that for $+X$ face. Fine pyramidal growth hills were observed on $Z$ face, and the size increased with increasing pressure and concentration of ammonium fluoride solution. The linear defect density in $Z$ growth zone was about $10^{3}-10^{5} \mathrm{pcs} / \mathrm{cm}^{2}$, higher than that in alkaline solutions. Strong absorption at about $3500 \mathrm{~cm}^{-1}$ by $-O H$ stretching vibration was observed in FTIR spectra. The defects originating from $-\mathrm{OH}$ depended on the temperature gradient.

Key-words : Quartz, Ammonium fuoride, Hydrothermal growth, Pyramidal growth hills

\section{1. 緒言}

水晶は，その高い溶解度を得るために，アルカリ水溶液 を溶媒とした水熱法により，比較的高温高圧条件で育成さ れている1)。このアルカリ水溶液以外に水晶に対し高い溶 解性を示す溶媒として，フッ化アンモ二ウム水溶液があ る.これは, 工業的にもガラス, 水晶等のエッチング加工 に用いられることは周知のとおりである。 そこで, フッ化 アンモニウム水溶液を溶媒として用い, 上り低温低圧条件 下での水晶の水熱育成を検討した。

本研究では，まずフッ化アンモニウム水溶液による，水 晶の溶解度を測定し，その水熱育成の可能性を検討した 後, 実際に, フッ化アンモ二ウム水溶液による水晶の水熱育 成を試みた。 また育成した水晶は，その成長速度を測定する とともに生成結晶の形態，及びその性質を評価してみた。

\section{2. 実験方法}

\section{1 水晶の溶解度}

溶解度測定には図 1 に示すようなテフロンを内張りした
ステンレス製の小型オートクレーブを使用した。この容器 内に，アルカリ水溶液で育成された水晶の破砕片数 $g$ と， 濃度を $10 \sim 40 \mathrm{wt} \%$ に調製したフッ化アンモニウム水溶液 を $80 \%$ の充填率で充填し，所定温度 $\left(160 \sim 250^{\circ} \mathrm{C}\right)$ で 120 時間以上保持した後, 降温による析出誤差を抑えるため, 水で急冷した. 冷却後, オートクレーブ内に残った水晶の 重量を測定し溶解度を算出した。

\section{2 水晶の水熱育成}

水晶の水熱育成に用いた実験装置の概略を図 2 に示す.

内容積 $170 \mathrm{ml}$ のオートクレーブを使用し，不純物の派 染を避けるため, テフロン容器の内側に種子と原料を充填 して実験を行った。育成は，濃度 3〜30 wt\%のフッ化ア ンモニウム水溶液を使用し, 育成温度 $230 \sim 280^{\circ} \mathrm{C}$ (温度勾 配 $25 \sim 40^{\circ} \mathrm{C}$ )，圧力 $4 \sim 101 \mathrm{MPa}$ の条件で10 20日間行っ た。得られた水晶は, 寸法測定により成長速度を求め（以 下に示す成長速度は，成長方向に垂直な正負両面の值の和 として表す)，実体顕微鏡により結晶の形態の観察を行っ た。更に，FTIRによる赤外吸収スペクトルの測定及び $\mathrm{X}$ 線トポグラフによる線状欠陥の評価を行った。

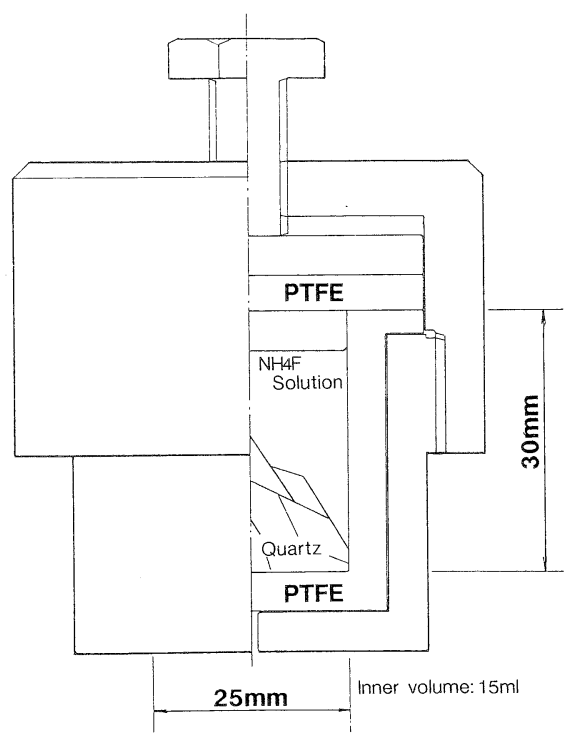

Fig. 1. Small autoclave for solubility measurement. 


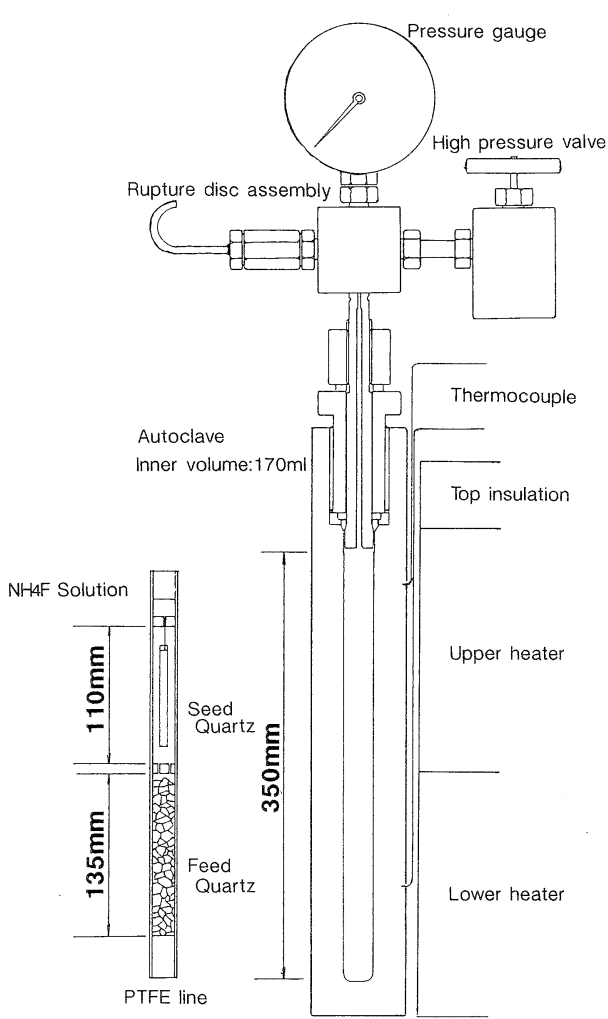

Fig. 2. Schematic arrangement for crystal growth.

\section{3. 結果及び考察}

\section{1 水晶の溶解度}

水晶の溶解度は, 温度の上昇とともに増加した。図 3 に 示すように, 溶解度の対数 $(\log S)$ と, 絶対温度の逆数 $(1 / T)$ との間には, van’t Hoffの平衡式（(1)式）によく 適合する比例関係がみられた。

$$
\begin{gathered}
\mathrm{dLog} S / \mathrm{d} T=\Delta E /\left(R T^{2}\right) \\
S: \text { 溶解度 }[\mathrm{mol} / \mathrm{kg}] \\
\Delta E: \text { 溶解熱 } \\
R: \text { ガス定数 } \\
T: \text { 絶対温度 }[\mathrm{K}]
\end{gathered}
$$

この図 3 の傾きから算出される $\Delta E$ (溶解熱) は，およ そ1.1〜1.6[kcal/mol] でめった.

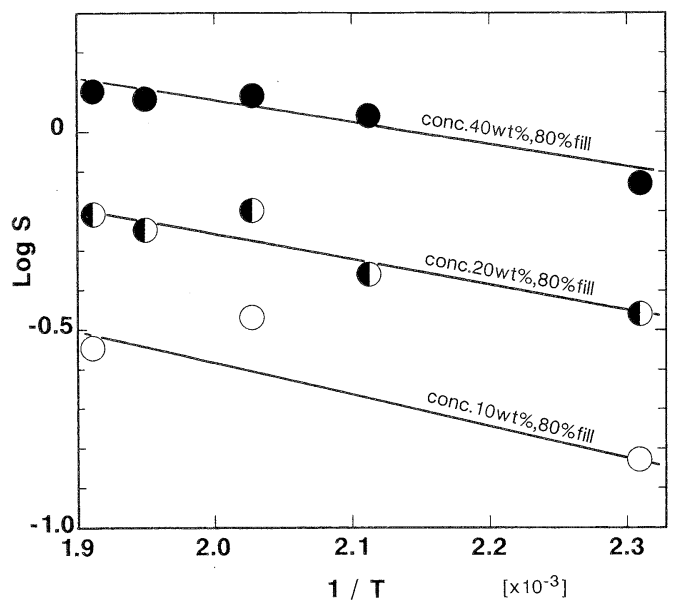

Fig. 3. Relation between $\log S$ and $1 / T$.
$0.5 \mathrm{~N}$ の $\mathrm{NaOH}$ 水溶液又は $\mathrm{Na}_{2} \mathrm{CO}_{3}$ 水溶液を用いて, $330 \sim 390^{\circ} \mathrm{C}$ で求められた $\Delta E$ は，それぞれ0.9, 5.2 $[\mathrm{kcal} / \mathrm{mol}]$ である。このためフッ化アンモニウム水溶液 によって得られた $\Delta E$ は, $\mathrm{NaOH}$ 水溶液に近い值と考え られる。

$0.5 \mathrm{~N} \mathrm{NaOH}$ 水溶液に対する水晶の溶解度は, $350^{\circ} \mathrm{C}$ で およそ2.8 お $^{2}$ [g/100 ml] であり，濃度 $20 \mathrm{wt} \%$ のッ化ア ンモニウム水溶液では, これと同程度の溶解度が, $250^{\circ} \mathrm{C}$ 以下の温度で得られた。 また $\mathrm{NaOH}$ 水溶液では $350^{\circ} \mathrm{C} に お ~$ いて，圧力が抢よそ100 MPa 程度である3)のに対し，フッ 化アンモニウム水溶液では, $250^{\circ} \mathrm{C}$ であっても $4 \mathrm{MPa}$ 程 度4)であり，非常に低圧である。

これらの現象は, フッ化アンモニウム水溶液による水晶 の溶解が (2)式5)に従うと予想されるためである.

$$
\begin{aligned}
3 \mathrm{NH}_{4}++3 \mathrm{HF}_{2}-+\mathrm{SiO}_{2}= & \left(\mathrm{NH}_{4}\right)_{2} \mathrm{SiF}_{6}+\mathrm{NH}_{3} \\
& +2 \mathrm{H}_{2} \mathrm{O}
\end{aligned}
$$

ここで生成するケイフッ化アンモニウム $\left(\left(\mathrm{NH}_{4}\right)_{2} \mathrm{SiF}_{6}\right)$ は，常温においても水に対し高い溶解度を持つ塩である。 このため, フッ化アンモ二ウム水溶液は, 低温低圧条件下 に扔いても, 水晶に対し高い溶解度を持ち, その育成が可 能であると予想される.

\section{2 水晶の水熱育成}

\section{2 .1 成長速度と育成条件の関係}

濃度 $10 \mathrm{wt} \%$ のフッ化アンモニウム水溶液を用いて育成 温度 $280^{\circ} \mathrm{C}$ で水晶を育成し, その成長速度と温度勾配の関 係について調べた。図4 はその結果を示したものである。 この図から成長速度は, 温度勾配に依存することが分か 万.

同様に, 成長速度は, 育成温度の上昇とともに速くな り，またフッ化アンモニウム水溶液の濃度の増加とともに 速くなった。これらの現象は，成長速度が，水晶の溶解度 及び過飽和度と密接に関連することを示している。これら

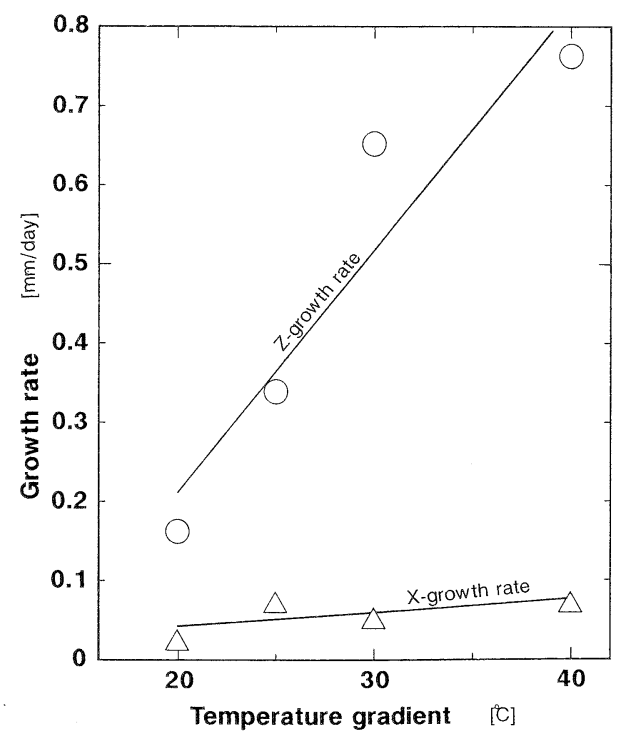

Fig. 4. Relation between growth rate and temperature gradient. $\bigcirc: Z$ axis direction, $\triangle: X$ axis direction. 
Table 1. Summary of experimental conditions.

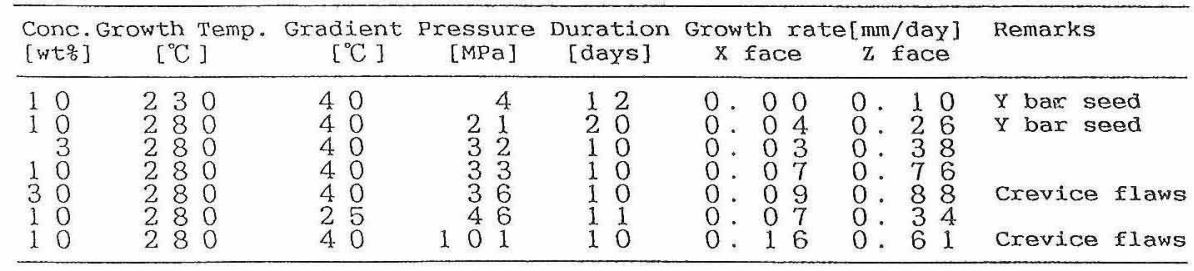

\section{の主な結果を表 1 に示す。}

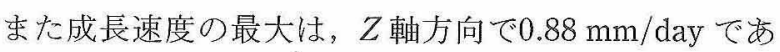
り，現在工業的に生産される水晶のそれが，拈よそ0.5 $\mathrm{mm} / \mathrm{day}$ であるとと考慮すると，本研究における成長 速度はかなり速いと考えられる。

\section{2 .2 結晶の形態}

成長した結晶の形態の概略を， $\mathrm{NaOH}$ 水溶液の場合と 比較して図 5 に示した。結晶の大きさは育成条件によって 変化するが，Z軸方向の成長を一定とし，それに対応する $X$ 軸方向の成長の違いでこの形態の比較を行った。この 図汃ら，フッ化アンモ二ウム水溶液により育成された水晶 は, $\mathrm{NaOH}$ 水溶液による水晶に比べ, $Z / X$ 比（ $Z$ 軸方向 とX軸方向の成長速度の比）が大きいことが明らかで市 る. 更にーX面の成長は非常に遅く, $+X$ 面の成長の 5 分の 1 以下で岁った。 また $\mathrm{NaOH}$ 水溶液の場合, $-X$ 面 側で生じる管型の $Z$ 成長領域は，欠落しており，これら 形態の特幑は, 八ロゲン化アルカリ水溶液，もしくは純水 によって育成された水晶の形態6)とよく似ていた。

更に大きな特徵は， $Z$ 面にみられる成長丘である. 水晶 を $\mathrm{NaOH}$ 水溶液で育成した場合，なだらかで丸みを帯び た成長丘が生じるのに対し，フッ化アンモニウム水溶液の 場合，成長丘は，三面ピラミッド型を示す。この現象から， $Z$ 面の成長機構が， $\mathrm{NaOH}$ 水溶液の場合と異なっている ことが考えられる。種々の育成条件で見られる成長丘の顕 微鏡写真を図 6 $(\mathrm{A} \sim \mathrm{D})$ に示す。 $\mathrm{A}$ は，濃度10 wt\%

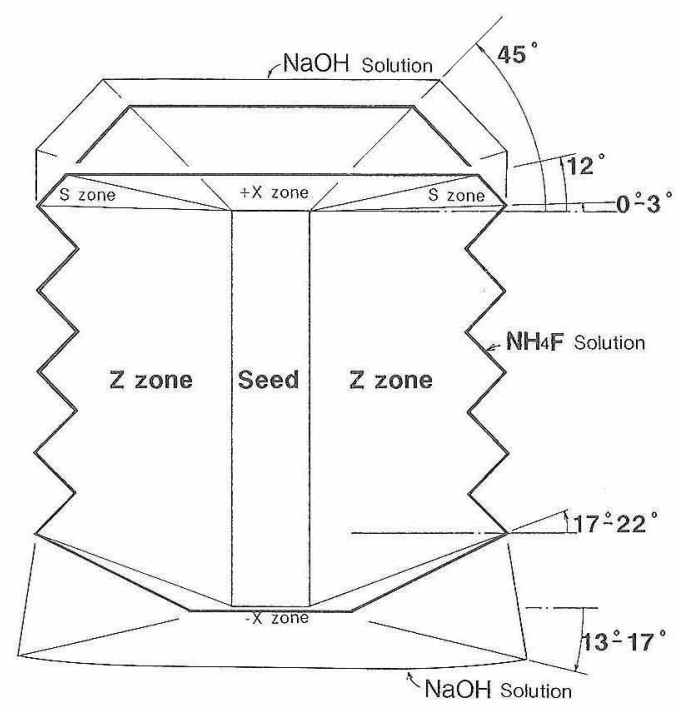

Fig. 5. Morphology of as-grown quartz.

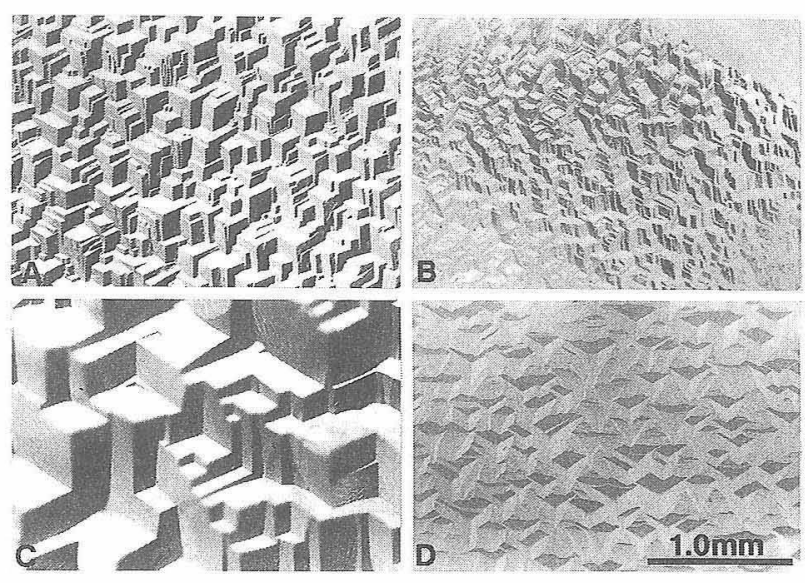

Fig. 6. Microphotograph of growth hills on $Z$ face. A : $10 \mathrm{wt} \%$ ammonium fluoricle solution at $280^{\circ} \mathrm{C}$ (temperature gradient was $40^{\circ} \mathrm{C}$ ) and $33 \mathrm{MPa}$.

$\mathrm{B}: 3 \mathrm{wt} \%$ ammonium fluoride solution at $280^{\circ} \mathrm{C}$ (temperature gradient was $40^{\circ} \mathrm{C}$ ) and $32 \mathrm{MPa}$.

$\mathrm{C}: 10 \mathrm{wt} \%$ ammonium fluoride solution at $280^{\circ} \mathrm{C}$ (temperature gradient was $40^{\circ} \mathrm{C}$ ) and $101 \mathrm{MPa}$.

D : $10 \mathrm{wt} \%$ ammonium fluoride solution at $280^{\circ} \mathrm{C}$ (temperature gradient was $25^{\circ} \mathrm{C}$ ) and $46 \mathrm{MPa}$.

フッ化アンモニウム水溶液、用いて育成温度 $280^{\circ} \mathrm{C}$, 温度 勾配 $40^{\circ} \mathrm{C}$ ，圧力 $33 \mathrm{MPa}$ で育成した水晶の $Z$ 面にみられ る成長丘である。これに対し Bは，濃度 3 wt\%のフッ化 アンモニウム水溶液を用いて，ほぼ同じ育成条件で育成し た水晶の成長丘であり，成長丘の大きさは，濃度 $10 \mathrm{wt} \%$ のフッ化アンモニウム水溶液に比べ小さいことが分かる。

また C は，王力を101 MPa なで上げて育成した水晶の成 長丘であり，33 MPaで育成された $\mathrm{A} の$ 成長丘と比較し て，大きく発達していることが分かる。更にDは，温度 勾配を $25^{\circ} \mathrm{C}$ 少さくして育成した水晶の成長丘であり，

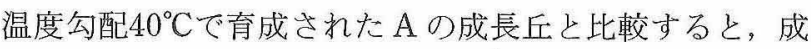
長丘は，ピラミッド型のその頂点部分が欠け，細かな凸凹 はむるものの，ほぼ平らな面に，ピラミッド型の凹部分の

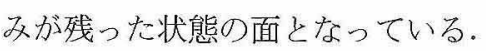

このように，成長丘の大きさは，育成条件に強く依存 し, フッ化アンモニウム水溶液の濃度及び圧力が高くなる ほど大きくなる傾向がある。成長丘が大きくなるに伴い， 結晶の表面付近に打ける，シリコンの拡散による供給の不 足のため7)，ピラミッド型の凹部から成長領域内にス (crevice flaws) の発生がみられた。表 1 にも示している ようにファッ化アンモ二ウム水溶液の濃度及び圧力が高い 条件では，このようなスが観察され，スと成長丘の大きさ とは，密接な関係があるものと考えられる。 

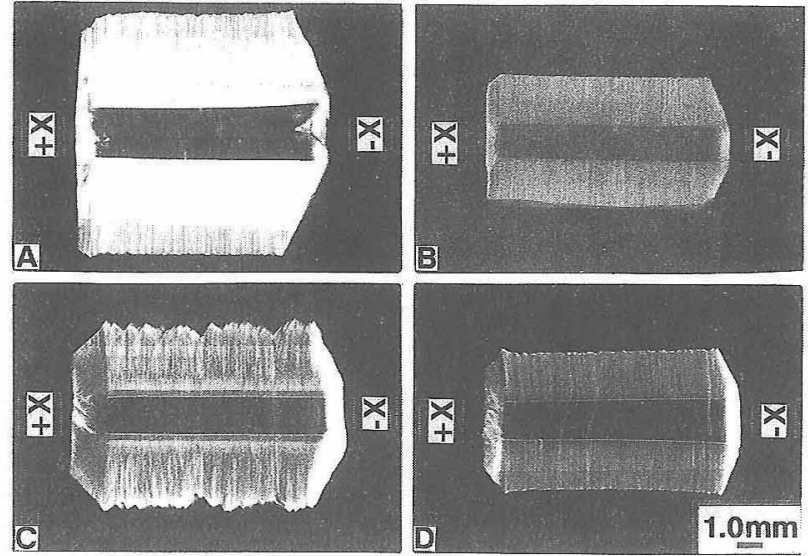

Fig. 7. X-ray topograph of $Y$ cut quartz. reflection (2īio), Mo $\left(\mathrm{k} \alpha_{1}\right)$.

A : $10 \mathrm{wt} \%$ ammonium fluoride solution at $280^{\circ} \mathrm{C}$ (temperature gradient was $40^{\circ} \mathrm{C}$ ) and $33 \mathrm{MPa}$

B : 3 wt $\%$ ammonium fluoride solution at $280^{\circ} \mathrm{C}$ (temperature gradient was $40^{\circ} \mathrm{C}$ ) and $32 \mathrm{MPa}$.

$\mathrm{C}: 10 \mathrm{wt} \%$ ammonium fluoride solution at $280^{\circ} \mathrm{C}$ (temperature gradient was $40^{\circ} \mathrm{C}$ ) and $101 \mathrm{MPa}$.

D : $10 \mathrm{wt} \%$ ammonium fluoride solution at $280^{\circ} \mathrm{C}$ (temperature gradient was $25^{\circ} \mathrm{C}$ ) and $46 \mathrm{MPa}$.

\section{2 .3 結晶内の欠陥}

図 $7(\mathrm{~A} \sim \mathrm{D})$ は， $\mathrm{X}$ 線トポグラフで観察される, 結晶内 の線状欠楩の状態を示したものである。Aは，濃度 10 wt \% のフッ化アンモニウム水溶液を用いて育成温度 $280^{\circ} \mathrm{C}$ ，温度勾配 $40^{\circ} \mathrm{C}$ ，压力 $33 \mathrm{MPa}$ で育成した水晶であ り，種子の近傍から伸びる線状欠陥の密度は， $Z$ 領域で $10^{5} \mathrm{pcs} / \mathrm{cm}^{2}$ オーダーに末で達するとみられる。写真でみ られる成長領域は，その写し出された線状欠陷のため，白 く見えている．これに対し B は，濃度 3 wt\%のフッ化ア ンモニウム水溶液を用いて，同じ育成条件で育成したもの であり，線状欠陥は，濃度 $10 \mathrm{wt} \%$ のッ化アンモニウム 水溶液に比べ，やや少なくなっており，104 pcs $/ \mathrm{cm}^{2}$ 程度 の密度である。おた $\mathrm{C}$ は，圧力を101 $\mathrm{MPa}$ まで上げて育 成した氷晶であり，圧力 $33 \mathrm{MPa}$ で育成された $\mathrm{A}$ の線状 欠陷と比較して，密度の減少がみられる。更にDは，温 度勾配を $25^{\circ} \mathrm{C}$ までさくして育成したもので，温度勾配 $40^{\circ} \mathrm{C}$ で育成された $\mathrm{A}$ と比較して，線状欠陥は非常に少な くなって扔り，その密度は $10^{3} \mathrm{pcs} / \mathrm{cm}^{2}$ オーダーにまで減 少していることが分かる。このように，線状欠陥の密度 は，育成条件に影響され，压力が高いほぼ，屯た溶液の濃 度，温度勾配が小さいほど減少することが明らかである。 水晶を電子デバイスとして応用する場合，その特性に影響 を与えない線状欠陷密度は $10^{2} \mathrm{pcs} / \mathrm{cm}^{2}$ オーダーであると 考えられる8)。このため, フッ化アンモニウム水溶液を用 いて水晶を育成する場合，更に温度勾配等の育成条件を調 整しなければならない。

また，Z成長領域に打ける赤外吸収スペクトルで， - $\mathrm{OH}$ 基の伸縮振動による $3500 \mathrm{~cm}^{-1}$ 付近の吸収 ${ }^{9), 10)}$ が強 くみられた。図8 $(\dot{A} \sim C)$ に扔いて, 破線で示したスペク トルは，濃度 $10 \mathrm{wt} \%$ のフッ化アンモニウム水溶液を用い

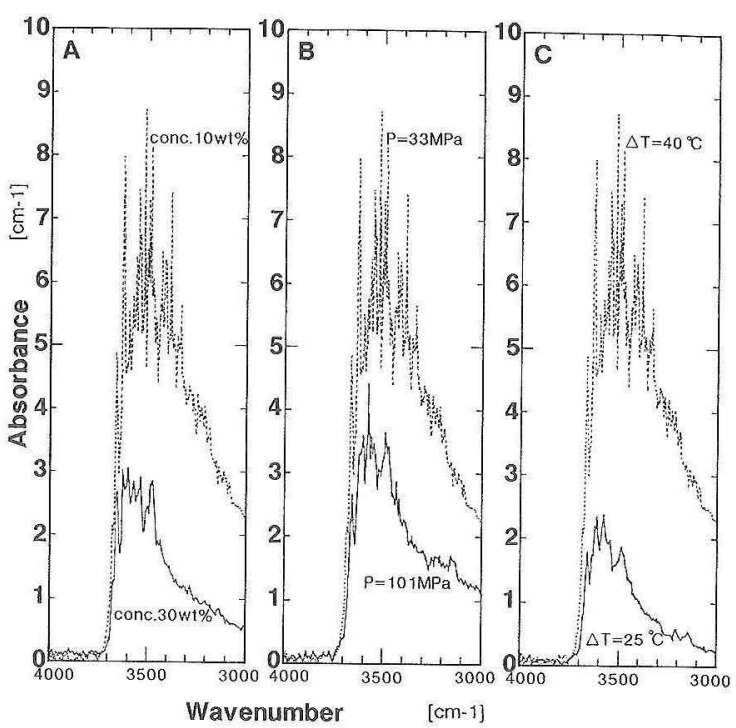

Fig. 8. Infrared absorption spectra.

: $10 \mathrm{wt} \%$ ammonium fluoride solution at $280^{\circ} \mathrm{C}$ (temperature gradient was $40^{\circ} \mathrm{C}$ ) and $33 \mathrm{MPa}$. : A ; $30 \mathrm{wt} \%$ ammonium fluoride solution at $280^{\circ} \mathrm{C}$ (temperature gradient was $40^{\circ} \mathrm{C}$ ) and $36 \mathrm{MPa}$.

B ; $10 \mathrm{wt} \%$ ammonium fluoride solution at $280^{\circ} \mathrm{C}$ (temperature gradient was $40^{\circ} \mathrm{C}$ ) and $101 \mathrm{MPa}$.

C ; $10 \mathrm{wt} \%$ ammonium fluoride solution at $280^{\circ} \mathrm{C}$ (temperature gradient was $25^{\circ} \mathrm{C}$ ) and $46 \mathrm{MPa}$.

て, 育成温度 $280^{\circ} \mathrm{C}$, 温度勾配 $40^{\circ} \mathrm{C}$, 圧力 $33 \mathrm{MPa}$ で育成 した水晶の赤外吸収スペクトルである。 $\mathrm{A}$ には，フッ化 アンモニウム水溶液の濃度を変えて育成した水晶のスペク トルを実線で示した。この㘠から分かるように，結晶内に 含むれるーOH 基は，溶液の濃度が高いほど減少する。 た Bには，圧力を変えて育成した水晶のスペクトルを実 線で示しており，この図からー $\mathrm{OH}$ 基は，压力が高いほど 減少することが分かる，更にCには，温度勾配を変えて 育成した水晶のスペクトルを実線で示しており，この図か らーOH 基は，温度勾配が小さいほど減少することが分か る、このように，結晶内に含まれるー OH 基は，フッ化ア ンモニウム水溶液の濃度，圧力が高いはど，そして温度勾 配が小さいほど抑えられる傾向がある。

線状欠陷や結晶内に含まれる一 $\mathrm{OH}$ 基が，比較的多い原 因上して, 水晶の溶解, 析出反心が，アルカリ水溶液と大 きく異なることが考えられる。すなわち，アルカリ水溶液 の場合 ( $\mathrm{NaOH}$ 水溶液の場合)，(3)式のように，ポリケ イ酸イオン $\left(\mathrm{Si}_{3} \mathrm{O}_{7}^{2-}\right)$ がシリコンの移動媒体となる2),3).

$$
2 \mathrm{OH}^{-}+3 \mathrm{SiO}_{2}=\mathrm{Si}_{3} \mathrm{O}_{7}^{2-}+\mathrm{H}_{2} \mathrm{O}
$$

これに対し，フッ化アンモニウム水溶液の場合，(4)式の ようにシリコンのフルオロ錯イオン $\left(\mathrm{SiF}_{6}{ }^{2-}\right)$ がその媒体 となる5).

$$
3 \mathrm{HF}_{2}{ }^{-}+\mathrm{SiO}_{2}=\mathrm{SiF}_{6}{ }^{2-}+\mathrm{OH}^{-}+\mathrm{H}_{2} \mathrm{O}
$$

このため, 析出反応に扔いて，そのシリコンに結合して いたフッ素が, 酸素で置換される必要が生じ, 比較的過飽 和度が低い条件であっても，このような欠陥が発生するも のと考えられる。 


\section{4. 結 論}

フッ化アンモニウム水溶液を用いて, 水晶の溶解度を測 定した結果, 水熱育成に必要とされる高い溶解度が得られ た.フッ化アンモニウム水溶液を用いることにより，より 低温低圧条件下で, 水晶の水熱育成が可能であった.

フッ化アンモニウム水溶液で育成される水晶は, 育成条 件により変化するが，以下の特徴があった.

（1） $Z$ 面は，アルカリ水溶液と同等の成長速度である が， $X$ 面の成長は非常に遅い。

（2）アルカリ水溶液にみられる袴型の $Z$ 成長領域が 欠落している。

（3） Z 面にみられる成長丘が三面ピラミッド型を示 す。

（4）線状欠陥は，フッ化アンモニウム水溶液の濃度 が低く，圧力が高いほど，また温度勾配が小さい ほど減少する。

（5）赤外吸収スペクトルで評価される $-\mathrm{OH}$ 基は, フッ化アンモニウム水溶液の濃度が高く, 育成温 度及び圧力が高いほど，そして温度勾配が小さい ほど抑えられる。
このように，フッ化アンモニウム水溶液を用いて水晶を 育成する場合, その温度勾配を小さくすることにより，得 られる水晶の性質が改善され, 電子デバイス用材料への応 用も可能と考えられる.

\section{文献}

1) I E C publication, 758.

2) 滝 貞男, 山田桂子, 山梨大学学芸部研究報告, 12, 14650 (1961).

3) E. D. Kolb, P. L. Key, R. A. Laudise and E. E. Simpson, Bell Syst. Tech. J, 62, 639-56 (1983).

4) L. A. Samoilovich, Zap. Vsesoyuzn. Mineral, 104, 110-12 (1975).

5) V. S. Balitsky, J. Cry. Gr., 41, 100-02 (1977).

6) 保坂正博, 工学博士論文, 北海道大学 (1982) pp. 22-138.

7) R. A. Laudise and R. L. Barns, IEEE Trans., 35, 277-87 (1988).

8) J. Asahara, K. Takazawa, E. Yazaki, J. Okuda and N. Asanuma, Proc. 28th. Annu. Freq. Contr. Symp., 29-31 May, 1974, Howard Johnson's Motor Lodge Atlantic City, New Jersey, pp. 117-24.

9) P. Cordir and J. C. Doukhan, Am. Miner., 76, 361-69 (1991).

10) M. S. Paterson, Bull. Mineral., 105, 20-29 (1982). 